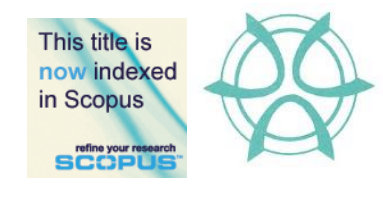

PLANNING MALAYSIA:

Journal of the Malaysian Institute of Planners

VOLUME 15 ISSUE 2 (2017), Page 109 - 122

\title{
AN EVALUATION OF URBAN PUBLIC TRANSPORT ROUTE. CASE STUDY: HOP-ON HOP-OFF, KUALA LUMPUR, MALAYSIA
}

\author{
Izzati Khairimah Ismail ${ }^{1}$, Oliver Ling Hoon Leh ${ }^{2}, \&$ Zulkifli Ahmad Zaki ${ }^{3}$ \\ ${ }^{1,2,3}$ Faculty of Architecture, Planning and Surveying \\ UNIVERSITI TEKNOLOGI MARA (UiTM)
}

\begin{abstract}
Urban public transportation system is a means of providing mobility to locals, visitors as well as tourists. KL Hop-On Hop-Off buses, for instance, are designed specifically for local and foreign tourists to move within the Kuala Lumpur (KL) city centre areas for the purpose of tourism. However, there is only one route provided by the KL Hop-On Hop-Off, with more than 20 stops. The duration for a complete route tour without any stop is too long; that is around 2-2 $1 / 2$ hours. Coupled with the problem of traffic congestion in KL, passengers face the problems of punctuality and long waiting periods. Thus, this study was carried out to evaluate the existing route of the KL Hop-On Hop-Off bus services. GIS application and questionnaire survey were used to evaluate the route. As a result, this study proposes three new routes as the alternatives to the existing single route Hop-On Hop-Off bus service. With the new routes, duration of a single full route tour can be reduced based on the interest of tourist. Tourists will be able to concentrate on just one part of KL city centre for their one-day tour based on their interest either heritage, shopping or nature.
\end{abstract}

Keywords: Hop-On Hop-Off bus, route, satisfaction, tourist, walking distance

Date Received: $26^{\text {th }}$ July 2016

Date of Acceptance: $6^{\text {th }}$ July 2017 
Izzati Khairimah Ismail, Oliver Ling Hoon Leh, \& Zulkifli Ahmad Zaki

An Evaluation of Urban Public Transport Route. Case Study: Hop-On Hop-Off, Kuala Lumpur, Malaysia

\section{INTRODUCTION}

Transport has been a necessary element of tourism from the early days of the pilgrimage; but technological developments have enabled tourists to travel longer distances and have facilitated the rapid growth of destinations (Lumsdon, 2006). This shows the importance of transportation to the development of tourism industry. In terms of public transportation, an urban area, such as Kuala Lumpur, may consists of bus services, light rail transit (LRT), commuter rail, airport rail and taxi. In Kuala Lumpur (KL), the public bus services comprise the city bus and the tourist bus. The city bus service consists of Rapid KL, City Liner, Metrobus and Selangor Omnibus. At the same time, there is also a tourist bus service within KL city centre area, called "KL Hop-On Hop-Off".

"Hop-On Hop-Off" is a brand that is owned, operated and managed by isango! Limited (2015). A Hop-On Hop-Off is a type of tourist bus service that follows a circular route with fixed stops through a city and allows paying passengers unlimited travel for a day (or other period of time) with the freedom to disembark at any stop and re-board another bus to continue their journey. Throughout the world, there are many cities that have this type of tourist bus service such as London, Paris, Amsterdam, New York, Singapore, Barcelona, Madrid, Granada, Las Vegas and Washington DC (isango! Limited, 2015). Table 1 shows examples of Hop-On Hop-Off bus services in a few cities.

Table 1 Hop-On Hop-Off Services in Few Cities

\begin{tabular}{|c|c|c|c|c|c|c|c|c|c|}
\hline \multirow{2}{*}{$\frac{\text { City }}{\text { Route }}$} & \multirow{2}{*}{$\frac{\mathrm{KL}}{1}$} & Penang & \multicolumn{2}{|l|}{ Rome } & \multicolumn{2}{|l|}{ Singapore } & \multicolumn{3}{|c|}{ London } \\
\hline & & City Beach & 1 & City & Original & Heritage & Original & 1 City & Museum \\
\hline $\begin{array}{l}\text { Frequency } \\
\text { (minutes) }\end{array}$ & 30 & $20-30$ & $15-20$ & 13 & $20-30$ & 20 & $10-30$ & $10-20$ & $10-30$ \\
\hline Full Loop & $\begin{array}{c}2 \mathrm{hr} 30 \\
\text { mins }\end{array}$ & No data & $\begin{array}{c}1 \mathrm{hr} 40 \\
\text { mins }\end{array}$ & $1 \mathrm{hr}$ & $\begin{array}{c}1 \mathrm{hr} 40 \\
\text { mins }\end{array}$ & $1 \mathrm{hr}$ & & hr $15 \mathrm{mi}$ & lins \\
\hline \multirow{3}{*}{$\begin{array}{l}\text { Operating } \\
\text { Hours }\end{array}$} & 9.00am & $9.00 \mathrm{am}$ & $9.00 \mathrm{am}$ & 8.30am & $9.30 \mathrm{am}$ & \multicolumn{2}{|c|}{ 9.40am8.30am } & 8.30am & $8.45 \mathrm{am}$ \\
\hline & - & - & - & - & - & - & - & - & - \\
\hline & $8.00 \mathrm{pm}$ & $8.00 \mathrm{pm}$ & $7.00 \mathrm{pm}$ & $6.30 \mathrm{pm}$ & $6.00 \mathrm{pm}$ & $5.15 \mathrm{pm}$ & $3.00 \mathrm{pm}$ & $5.20 \mathrm{pm}$ & $5.10 \mathrm{pm}$ \\
\hline $\begin{array}{l}\text { No. of } \\
\text { designated } \\
\text { stop }\end{array}$ & 22 stops & $\begin{array}{c}33 \\
\text { stops }\end{array}$ & 10 stops & $\begin{array}{c}21 \\
\text { Stops }\end{array}$ & 24 Stops & $\begin{array}{c}19 \\
\text { Stops }\end{array}$ & $\begin{array}{c}32 \\
\text { Stops }\end{array}$ & $\begin{array}{c}35 \\
\text { Stops }\end{array}$ & $\begin{array}{c}17 \\
\text { Stops }\end{array}$ \\
\hline
\end{tabular}

Sources: EWSB (2014); isango! Limited (2015)

Kuala Lumpur also has its own version of Hop-on Hop-off bus service, which is managed and operated by Elang Wah Sdn Bhd (EWSB, 2014). It provides 22 designated stops around 40 attractions in KL (EWSB, 2014). However, Hop-On Hop-Off bus does not seem to attract many tourists to take the bus services especially during rush hours where tourists might have to wait for a considerably long time to board the bus. Traffic congestion in the city centre has often resulted in some of the passengers were unable to take the bus on time to 
return to their starting point during rush hours (evening). Furthermore, most of the passengers were only able to visit a small number of the designated stops in a day. These prompted the authors to conduct this study to evaluate the existing route of the KL Hop-On Hop-Off bus. As mentioned by Lumsdon (2006) there is lacking of established body of research on the design of tourism bus services even in a developed country such as the United Kingdom.

\section{PUBLIC TRANSPORT ROUTE PLANNING}

A good public transport system is aimed to accommodate vast number of individual trips. It is designed to offer convenient links between all points where there is demand (Public-Private Infrastructure Advisory Facility, 2006). According to Ibarra-Rojas et al. (2014), transit network (routes) planning covers the following subjects:

a) Transit network (routes) design: Defines the lines layouts and associated operational characteristics such as rolling stock types and space between stops to optimise specific objective functions such as minimization of the weighted sum of operators' and users' costs.

b) Frequency setting for peak and non-peak hours.

c) Defines arrival and departure times of buses at all stops by meeting different goals such as meet a given frequency, satisfy specific demand patterns, maximise the number of well-timed passenger transfers, and minimise waiting times.

d) Determines the trips-vehicles assignment to cover all the planned trips with minimum operational cost.

e) Driver scheduling and rostering.

Route design deals with determining the origin, destination, intermediate stops, and path for each bus route in the network. An example of this type of research is a hybrid coverage model for strategic planning to expand service access and increase accessibility of bus stops. This includes the relocation of bus stops to maximal coverage locations in an existing network to minimise the number of bus stops and optimise the location of bus stops to create or extend the network (Sorussa, 2014).

In designing a bus route, there are seven types of bus services and routing, which are listed below (Grava, 2003):

a) Shuttle model: a single path between two points where the frequency of route depending on demand.

b) Radial patterns-through-running: provides services for the journey to work. It is effective as long as there is a concentration of employment. 
Izzati Khairimah Ismail, Oliver Ling Hoon Leh, \& Zulkifli Ahmad Zaki

An Evaluation of Urban Public Transport Route. Case Study: Hop-On Hop-Off, Kuala Lumpur, Malaysia

c) Radial patterns-return-running: resembles the shape of a star in which to focus on important routes in the middle of it.

d) Grid network: relatively straight line, parallel routes where there are spaces between it and intersect the paths of the same character.

e) Feeder service: local routes to feed heavier transit modes such as commuter train in a city.

f) Trunk line: different buses will travel at the same route at different intervals.

g) Loops and circulation: bus moves in one way repeatedly on a fixed route.

\section{RESEARCH METHODOLOGY}

\section{Case Study}

For this particular research, KL Hop-On Hop-Off was chosen as the case study. KL Hop-On Hop-Off runs seven (7) days a week. The bus runs in a circular loop daily with the first bus is at $9.00 \mathrm{am}$ until the last bus at $8.00 \mathrm{pm}$ with a 30 minutes intervals. Throughout the route, there are 23 designated stops in KL city centre area. Passengers can purchase the bus ticket at the main ticket counter, authorised agents and via on-line. There are two types of ticket, one is valid for 24 hours and another for 48 hours. The route begins and ends at Jalan Ampang, which covers the following roads:

- JalanGereja,

- Jalan Raja Chulan,

- Jalan P. Ramlee,

- JalanPuncak,

- Jalan Pinang,

- Jalan Kia Peng,

- JalanStonor,

- JalanConlay,

- Jalan Bukit Bintang,

- JalanTengkat Tong Shin,

- JalanChangkat Bukit Bintang,

- JalanTun Perak,

- JalanTun Tan Cheng Lock,

- Jalan Sultan,

- Jalan Hang Jebat,

- Jalan Sultan Muhamed,

- Jalan Hang Jebat,
- Jalan Sultan Muhamed,

- Jalan Istana,

- Jalan Travers,

- JalanTunSambanthan,

- JalanStesenSentral,

- JalanDamansara,

- JalanParlimen,

- JalanCenderawasih,

- JalanPerdana,

- Jalan Sultan Hishammudin,

- Jalan Raja,

- Jalan Raja Laut,

- Jalan Ipoh,

- Jalan Pahang,

- JalanTunRazak,

- LorongKuda,

- JalanBinjai 


\section{Scope of Study}

This study focus on the KL Hop-On Hop-Off route, distribution of tourist spots and shopping areas, and satisfaction of passengers (respondents) on the distance to bus stop from hotel, number of bus stop available, number of tourism destination that can be covered, duration of one complete route tour, frequency, and punctuality.

\section{Questionnaire Survey and Sampling of Respondents}

A questionnaire survey was carried out in January, 2016 to obtain views/feedback from passengers. The questionnaire covers the following aspects:

a) Background of respondents, i.e. age, origin, purpose of travel and type of ticket.

b) Satisfaction of respondents on the distance to bus stop, number of bus stop, number of tourism destination covered, duration of one complete route tour, frequency, and punctuality.

A total of 83 respondents were selected among passengers including both locals and foreign tourists, and from different age groups. Simple random sampling technique was used for this purpose. In general, the majority of the respondents $(75.9 \%)$ were foreign tourists. About two-third of the respondents purchased the 24-hour ticket while around $80 \%$ of respondents did not travel in a group. The background of respondents is as shown in Table 2 .

Table 2 Background of Respondents

\begin{tabular}{ll}
\hline Variables & Percentage (\%) \\
\hline Age & \\
\hline 21-30 years old & 21.7 \\
31-40 years old & 25.3 \\
41-50 years old & 34.9 \\
$>50$ years old & 18.1 \\
\hline Origin & \\
\hline Foreign & 75.9 \\
Local & 24.1 \\
\hline Purpose of trip & \\
\hline Leisure & 86.7 \\
Working & 13.3 \\
\hline Type of ticket & \\
\hline 24-hour & 66.3 \\
48-hour & 33.7 \\
\hline
\end{tabular}

Travel in group 
Izzati Khairimah Ismail, Oliver Ling Hoon Leh, \& Zulkifli Ahmad Zaki

An Evaluation of Urban Public Transport Route. Case Study: Hop-On Hop-Off, Kuala Lumpur, Malaysia

$\begin{array}{lr}\text { Yes } & 20.5 \\ & \\ & \end{array}$

No $\quad 79.5$

\section{Method of Analysis}

Existing route of KL Hop-On Hop-Off was analysed based on the coverage of KL's tourist destinations (tourist spots and shopping areas) by using geographic information system (GIS) buffering technique via MapInfo. Meanwhile, the satisfaction of respondents (passengers) on the aspects of duration, the number of bus stops can be utilised, frequency and punctuality were analysed using crosstabulation and frequency tests as available in Statistical Package for Social Sciences (SPSS). At the end of the study, alternatives of new routes were analysed based on the criteria of distance, number of destinations covered and identity/character of an area. For the purpose of calculating the travelling time for the new routes, general road condition in a working day (21 January 2016, Thursday) during the non-peak hour (10.30-11.30am) was used to model the new routes.

\section{RESULTS AND FINDINGS}

\section{Concentration of tourist spots and shopping places}

There were more than 50 tourist spots scattered in Kuala Lumpur city centre area. For the purpose of this study, KL city centre area was divided into four (4) quadrants. Based on the data (Figure 1), most of the tourist spots concentrated in quadrant 2 and 4. In quadrant 1, there were only five (5) tourist spots: the National Palace, Putra World Trade Centre (PWTC), Malaysian Parliament, National Monument and ASEAN Sculpture Garden. While in quadrant 2, there were 25 tourist spots including the most iconic buildings in Kuala Lumpur: the KLCC and the KL Tower. In quadrant 3, 13 tourist spots were identified, and most of them were natural/green areas and museums. In quadrant 4 , there were 22 tourist spots, mostly historical attractions such as Dataran Merdeka, Stadium Merdeka, Petaling Street, Sultan Abdul Samad Building and also shopping complexes. 


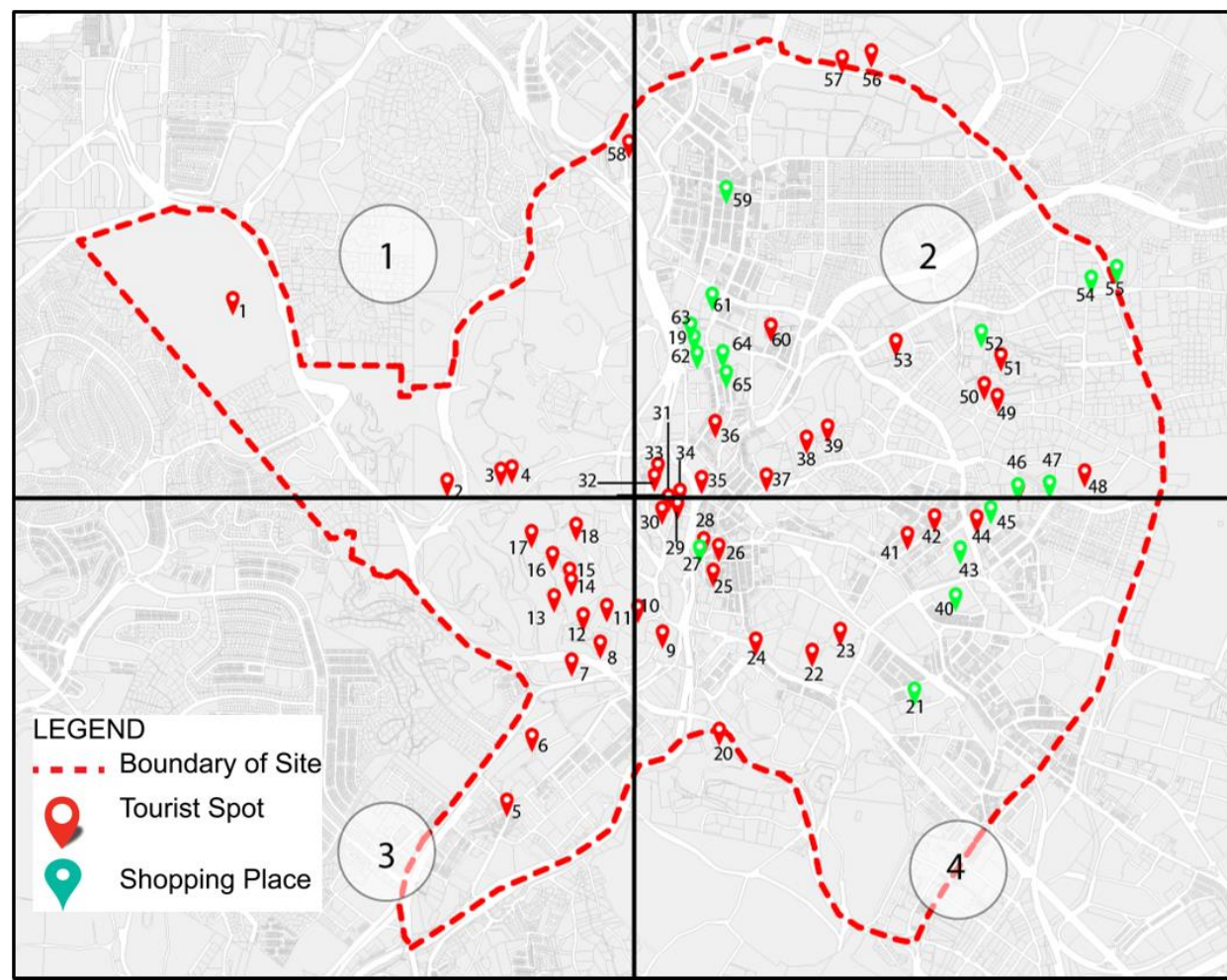

Figure 1 Distribution of Tourist Spots and Shopping Places

\section{Existing Route and Location of Bus Stops}

Currently, for KL Hop-On Hop-Off, there is only one route. The route is in a loop. This route has 23 stops along it. Based on observation conducted on 13th, 15 th and 17th of January, 2016, one complete loop took $2 \frac{1}{2}-3$ hours. The frequency of service was 20-30 minutes. By referring to the buffering analysis with $400 \mathrm{~m}$ for each bus stops (Figure 2), it is revealed that tourists can walk to more than one tourist spots from a bus stop. The 23 bus stops were covering 48 tourist spots and 17 shopping places in KL city centre area. There were only 11 tourist spots located out of walking distance from bus stops. Based on the satisfaction of respondents, most (95.2\%) of the respondents were satisfied or felt neutral with the distance (by walking) between bus stops and tourist spots. Meanwhile, most of the respondents felt neutral or satisfied with the distance between bus stops and hotels (Table 3). Most of the respondents took not more than 15 minutes to walk from their hotel to the nearest bus stop. 
Izzati Khairimah Ismail, Oliver Ling Hoon Leh, \& Zulkifli Ahmad Zaki

An Evaluation of Urban Public Transport Route. Case Study: Hop-On Hop-Off, Kuala Lumpur, Malaysia

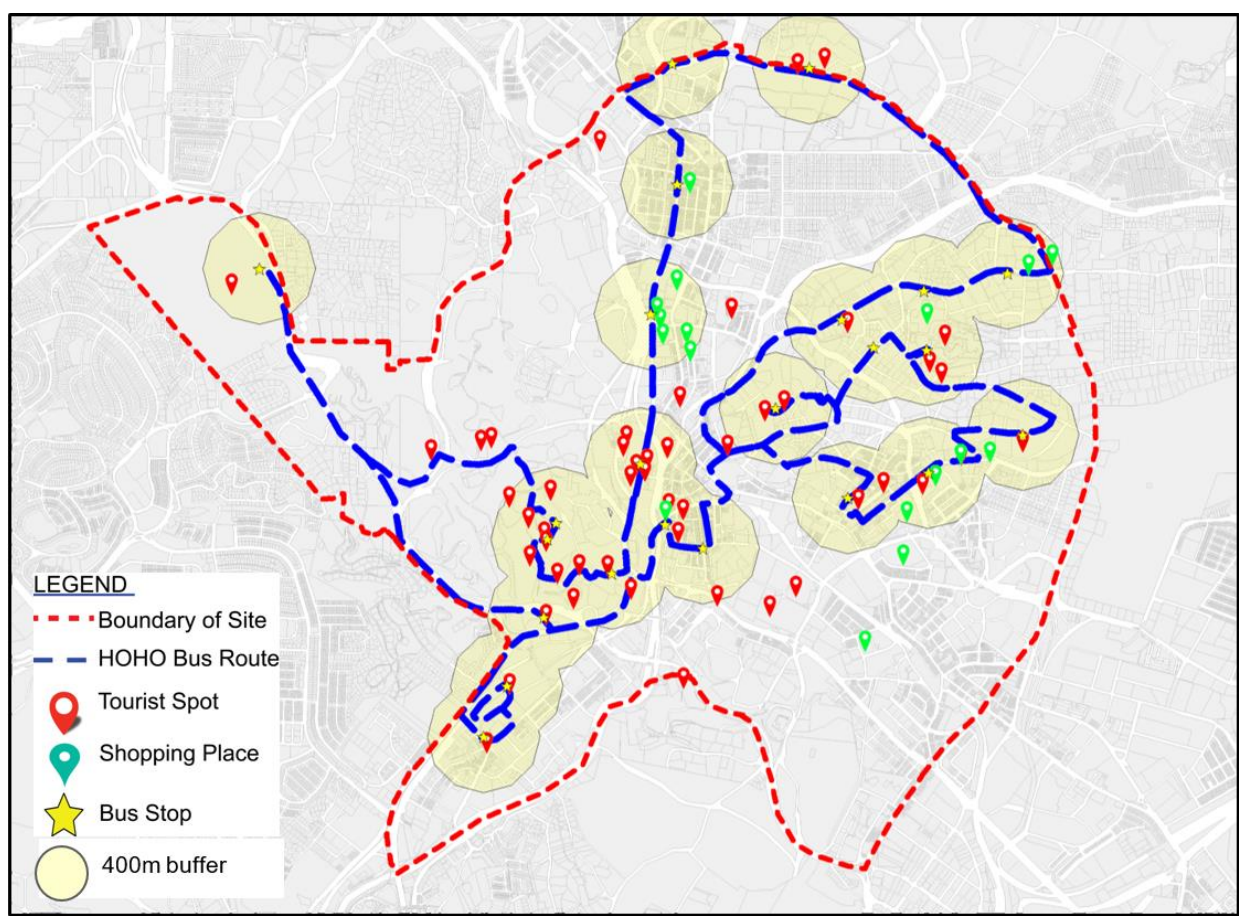

Figure 2 Existing Route, Location of Bus Stops and Buffering Analysis

Table 3 Satisfaction Level and Walking Distance from Hotel to Bus Stop

\begin{tabular}{llcccc}
\hline & & \multicolumn{3}{c}{ Satisfaction level } & Total \\
\cline { 2 - 5 } & & Dissatisfied & Neutral & Satisfied & \\
\hline Walk & $0-5$ & 0 & 2 & 5 & $7(8.43 \%)$ \\
from & $6-10$ & 0 & 16 & 19 & $35(42.17 \%)$ \\
hotel to & $11-15$ & 4 & 23 & 7 & $34(40.96 \%)$ \\
bus stop & $16-20$ & 0 & 3 & 2 & $5(6.02 \%)$ \\
(in min) & $>30$ & 0 & 0 & 2 & $2(2.41 \%)$ \\
\hline Total & & $4(4.82 \%)$ & $44(53.01 \%)$ & $35(42.17 \%)$ & $83(100 \%)$ \\
\hline
\end{tabular}

However, out of the total 23 bus stops, most (97.59\%) of the respondents only could utilise not more than 15 bus stops (Table 4$)$. More than half $(61.44 \%)$ of respondents were only able to utilise not more than 10 bus stops. Only $14.46 \%$ of respondents were satisfied with the number of bus stop that can be utilised by them (Table 4). 
PLANNING MALAYSIA

Journal of the Malaysia Institute of Planners (2017)

Table 4 Satisfaction Level and Number of Stop Utilized by Respondents

\begin{tabular}{|c|c|c|c|c|c|c|}
\hline & & \multicolumn{4}{|c|}{ Satisfaction level } & \multirow[b]{2}{*}{ Total } \\
\hline & & $\begin{array}{c}\text { Very } \\
\text { Dissatisfied }\end{array}$ & Dissatisfied & Neutral & Satisfied & \\
\hline \multirow{4}{*}{$\begin{array}{l}\text { No of stop } \\
\text { utilized by } \\
\text { respondent }\end{array}$} & $<5$ & 0 & 12 & 4 & 3 & $\begin{array}{c}19 \\
22.89 \%\end{array}$ \\
\hline & $5-10$ & 0 & 9 & 14 & 7 & $\begin{array}{c}32 \\
38.55 \%\end{array}$ \\
\hline & $\begin{array}{l}11- \\
15\end{array}$ & 2 & 21 & 7 & 2 & $\begin{array}{c}30 \\
36.14 \%\end{array}$ \\
\hline & $>15$ & 0 & 0 & 2 & 0 & $\begin{array}{c}2 \\
2.41 \%\end{array}$ \\
\hline Total & & $\begin{array}{c}2 \\
2.41 \%\end{array}$ & $\begin{array}{c}42 \\
50.60 \%\end{array}$ & $\begin{array}{c}27 \\
32.52 \%\end{array}$ & $\begin{array}{c}12 \\
14.46 \%\end{array}$ & $\begin{array}{c}83 \\
100 \%\end{array}$ \\
\hline
\end{tabular}

Furthermore, most of the respondents were only able to cover not more than 15 tourist destinations (Table 5), which contributed to the dissatisfaction of respondents on this matter. In the context of tourist destinations, only $7.23 \%$ of respondents were satisfied with numbers of attractions area covered by them (Table 5).

Table 5 Satisfaction Level and Number of Tourist Destinations Covered by Respondents

\begin{tabular}{|c|c|c|c|c|c|c|}
\hline & & \multicolumn{4}{|c|}{ Satisfaction level } & \multirow[b]{2}{*}{ Total } \\
\hline & & $\begin{array}{c}\text { Very } \\
\text { Dissatisfied }\end{array}$ & Dissatisfied & Neutral & Satisfied & \\
\hline \multirow{3}{*}{$\begin{array}{l}\text { No. of } \\
\text { tourist } \\
\text { destination } \\
\text { covered }\end{array}$} & $5-10$ & 2 & 13 & 16 & 4 & $\begin{array}{c}35 \\
42.27 \%\end{array}$ \\
\hline & $\begin{array}{l}11- \\
15\end{array}$ & 2 & 14 & 29 & 2 & $\begin{array}{c}47 \\
56.60 \%\end{array}$ \\
\hline & $>15$ & 0 & 1 & 0 & 0 & $\begin{array}{c}1 \\
1.20 \%\end{array}$ \\
\hline Total & & $\begin{array}{c}4 \\
4.82 \%\end{array}$ & $\begin{array}{c}28 \\
33.73 \%\end{array}$ & $\begin{array}{c}45 \\
54.2 \%\end{array}$ & $\begin{array}{c}6 \\
7.23 \%\end{array}$ & $\begin{array}{c}83 \\
100 \%\end{array}$ \\
\hline
\end{tabular}

Regarding duration of one complete tour, most of the respondents were either neutral or dissatisfied with the duration (Table 6). About $66 \%$ of the respondents experienced 2 to $2 \frac{1}{2}$ hours for one complete tour without any stop. However, one-third of respondents experienced more than $2 \frac{1}{2}$ hours for one complete tour without any stop. 
Izzati Khairimah Ismail, Oliver Ling Hoon Leh, \& Zulkifli Ahmad Zaki

An Evaluation of Urban Public Transport Route. Case Study: Hop-On Hop-Off, Kuala Lumpur, Malaysia

Table 6 Satisfaction Level and Time Taken to Complete One Tour

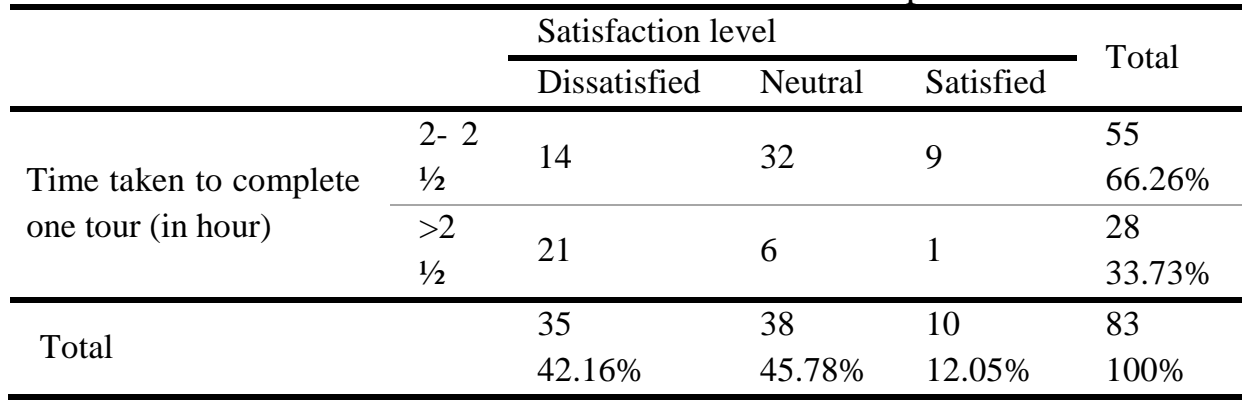

In general, most of the respondents were not satisfied with the existing route of KL Hop-On Hop-Off. Around 58\% of respondents were dissatisfied or very dissatisfied, $19 \%$ neutral, and only $23 \%$ of them were satisfied with the route. There was only one route available for the KL Hop-On Hop-Off service and it took too long to complete one complete tour without stop. Furthermore, most of the respondents were unable to utilise all of the 23 bus stops and visit the nearby tourist destinations.

The respondents, in general, felt that they were paying more than their ability to utilise the service. However, the respondents were satisfied with the current level of punctuality and frequency (waiting period) of the service.

\section{Proposing New Shorter Routes}

Based on the findings discussed above, an analysis was carried out to identify shorter routes for KL Hop-On Hop-Off service based on the following criteria:

a) Number of bus stop should be less than 10. Passengers (tourists) should be able to utilise most of the stops and cover most of the tourist destinations in the vicinity;

b) Duration to complete the new route should be not more than an hour, without stop; and

c) Clustering of tourist spots based on character.

As a result, three shorter routes are proposed as alternatives to the existing single route for Hop-On-Hop-Off bus in Kuala Lumpur (Figure 3). With these new routes, Hop-On Hop-Off bus can cover up to $6.15 \%$ more tourist destinations with four new bus stops. It will provide more choices of routes and tourist destinations for tourists. Masjid Jamek has been identified as the new common stop for each of the routes due to its strategic location, which is located in the heart of Kuala Lumpur and as a symbolic point of origin of Kuala Lumpur. With these new routes, tourists would be able to choose any attraction spots based on their interest more conveniently. 


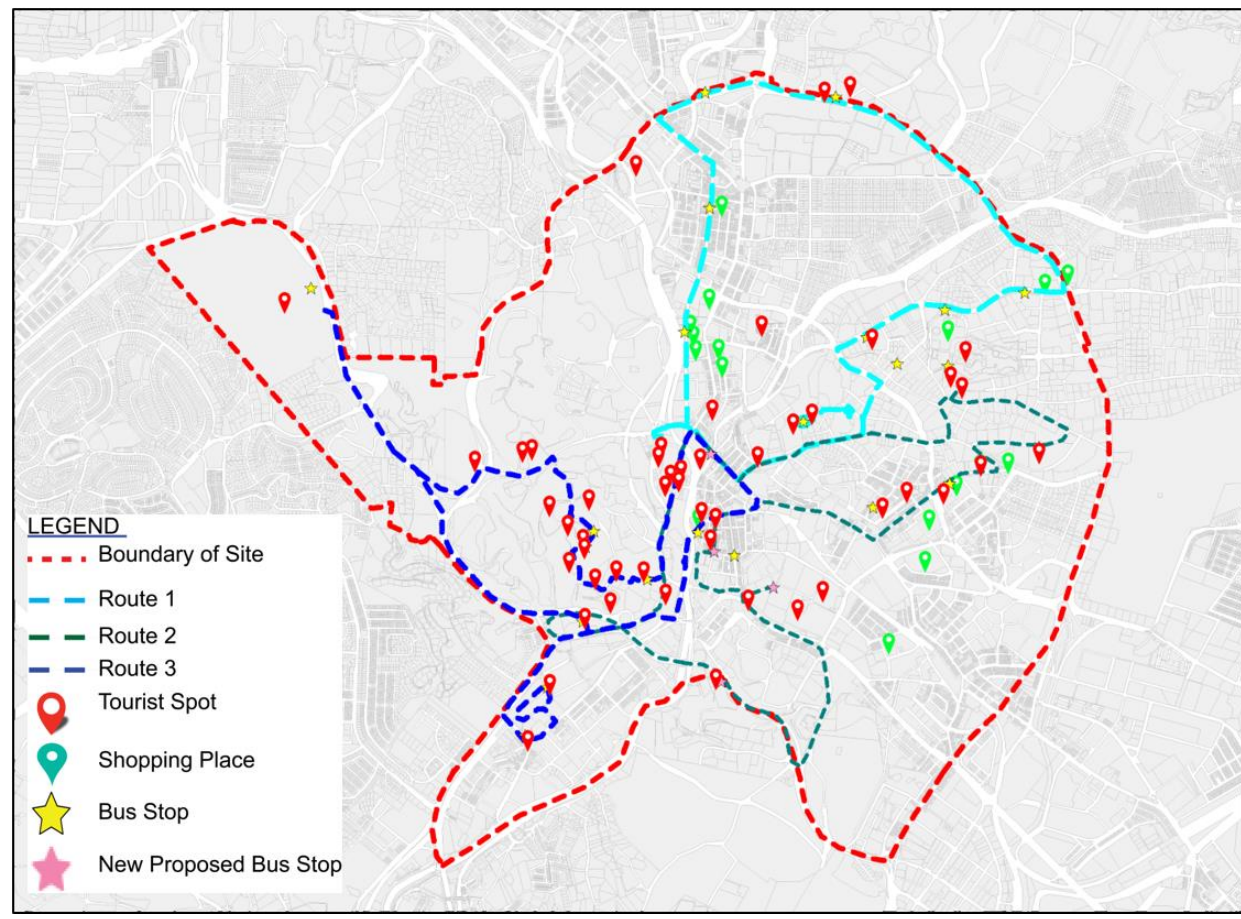

Figure 3 Proposed New Routes, Location of Bus Stops and Tourist Destinations

The proposed Route 1 has 9 bus stops with 23 tourist destinations (Table 7). The length is $12.85 \mathrm{~km}$ and duration to complete one loop is 37 minutes without stop. Most of the shopping places in Kuala Lumpur city centre, as well as iconic buildings in Kuala Lumpur such as KLCC, KL Tower and Masjid Jamek, are covered in Route 1.

Table 7 Coverage and Length of Route 1

\begin{tabular}{llll}
\hline $\begin{array}{l}\text { Number of } \\
\text { stop }\end{array}$ & Coverage & $\begin{array}{l}\text { Duration (Minutes } \\
\text { normal working day) }\end{array}$ & in \\
\hline $1 \rightarrow 2$ & Jalan Ampang & 2 & 0.75 \\
\hline $2 \rightarrow 3$ & Jalan Sultan Ismail & 6 & 2.00 \\
\hline $3 \rightarrow 4$ & Jalan Raja Chulan & 8 & 2.70 \\
& Jalan Tun Perak & & 1.60 \\
\hline 45 & Jalan Tun Perak & 6 & 0.85 \\
\hline $5 \rightarrow 6$ & Jalan Parlimen & & 1.40 \\
\hline $6 \rightarrow 7$ & Jalan Raja Laut & 4 & 0.85 \\
\hline $7 \rightarrow 8$ & Jalan Sultan Azlan Shah & 4 & \\
\hline
\end{tabular}


Izzati Khairimah Ismail, Oliver Ling Hoon Leh, \& Zulkifli Ahmad Zaki

An Evaluation of Urban Public Transport Route. Case Study: Hop-On Hop-Off, Kuala Lumpur, Malaysia

\begin{tabular}{llll}
$8 \rightarrow 9$ & Jalan Tun Razak & 5 & 2.70 \\
\hline Total & 37 & 12.85 \\
\hline
\end{tabular}

For proposed Route 2, there are 8 bus stops whereby 4 of them are newly proposed stops (Table 8 ). The length of the route is $15.9 \mathrm{~km}$ and takes 45 minutes to complete one loop without stop. Along this route, there are 25 tourist destinations that can be visited by tourists/passengers. This route emphasises on culture and shopping in Kuala Lumpur.

Table 8 Coverage and Length of Route 2

\begin{tabular}{|c|c|c|c|}
\hline $\begin{array}{l}\text { Number of } \\
\text { stop }\end{array}$ & Coverage & $\begin{array}{l}\text { Duration (Minutes in } \\
\text { working day) }\end{array}$ & Distance $(\mathrm{km})$ \\
\hline $9 \rightarrow 10$ & $\begin{array}{l}\text { Jalan Raja } \\
\text { Jalan Tun Perak }\end{array}$ & 4 & 0.5 \\
\hline $10 \rightarrow 11$ & $\begin{array}{l}\text { Jalan Tun Perak } \\
\text { Jalan Raja Chulan } \\
\text { Jalan P. Ramlee } \\
\text { Jalan Pinang }\end{array}$ & 8 & 2.4 \\
\hline $11 \rightarrow 12$ & $\begin{array}{l}\text { Jalan Pinang } \\
\text { Jalan Kia Peng }\end{array}$ & 5 & 1.5 \\
\hline $12 \rightarrow 13$ & $\begin{array}{l}\text { Jalan Conlay } \\
\text { Jalan Bukit Bintang }\end{array}$ & 5 & 1.4 \\
\hline $13 \rightarrow 14$ & $\begin{array}{l}\text { Jalan Bukit Bintang } \\
\text { Jalan Pudu }\end{array}$ & 6 & 2.2 \\
\hline $14 \rightarrow 15$ & Jalan Tun H. S. Lee & 4 & 1.2 \\
\hline $15 \rightarrow 16$ & Jalan Istana & 6 & 3.1 \\
\hline $16 \rightarrow 17$ & Jalan Damansara & 7 & 3.6 \\
\hline Total & & 45 & 15.9 \\
\hline
\end{tabular}

For Route 3, it has 10 bus stops with 26 tourist destinations (Table 9). The length is $16.5 \mathrm{~km}$ and takes 41 minutes to complete one loop without stop. Route 3 focuses on the scenic and panoramic areas of Kuala Lumpur due to the presence of green/natural areas and museums along the route.

Table 9 Coverage and Length of Route 3

\begin{tabular}{llll}
\hline $\begin{array}{l}\text { Number of } \\
\text { stop }\end{array}$ & Coverage & $\begin{array}{l}\text { Duration (Minutes in } \\
\text { working day) }\end{array}$ & Distance $(\mathrm{km})$ \\
\hline $9 \rightarrow 18$ & $\begin{array}{l}\text { JalanTun Perak } \\
\text { JalanTun Tan Cheng Lock }\end{array}$ & 5 & 1.5 \\
$18 \rightarrow 19$ & JalanDamansara & 6 & 2.6 \\
$19 \rightarrow 20$ & JalanSentral & 3 & 1.1 \\
\hline
\end{tabular}


PLANNING MALAYSIA

Journal of the Malaysia Institute of Planners (2017)

\begin{tabular}{llll}
\hline $20 \rightarrow 21$ & JalanSentral & 4 & 1.4 \\
$21 \rightarrow 22$ & JalanDamansara & 6 & 3.7 \\
$22 \rightarrow 23$ & JalanTunkuabdulHatim & 9 & 3.7 \\
$23 \rightarrow 24$ & JalanCenderawasih & 2 & 0.5 \\
$24 \rightarrow 25$ & JalanPerdana & 3 & 1 \\
$25 \rightarrow 26$ & Jalan Sultan Hishamuddin & 3 & 1 \\
\hline Total & & 41 & 16.5 \\
\hline
\end{tabular}

\section{CONCLUSION}

The findings of this study showed that existing single route Hop-On Hop-Off service for Kuala Lumpur did not draw maximum satisfaction from tourists/passengers. The route was affected by traffic congestion in the city centre and took too long to complete. As a result, this study proposes three new alternative routes that are shorter to complete. Each of the new routes focuses on the different types of tourist attractions in Kuala Lumpur. This would provide choices to tourists on which area they would like to visit based on their interests.

\section{ACKNOWLEDGEMENT}

The authors would like to thank Faculty of Architecture, Planning \& Surveying (FSPU), Universiti Teknologi MARA (UiTM) for supporting the study. The authors would also like to thank all the government departments, private companies, organisations and individuals who had contributed to this study. 
Izzati Khairimah Ismail, Oliver Ling Hoon Leh, \& Zulkifli Ahmad Zaki

An Evaluation of Urban Public Transport Route. Case Study: Hop-On Hop-Off, Kuala Lumpur, Malaysia

\section{REFERENCES}

Elang Wah Sdn. Bhd. [EWSB] (2014). KL Hop-On Hop Off. Retrieved October, 2015 from http://www.myhoponhopoff.com/kl/index.php

Grava, S. (2003). Urban transportation systems: choices for communities. New York: McGraw-Hill.

Ibarra-Rojas, O. J., Delgado, F., Giesen, R., \& Murioz, J. C. (2015). Planning, operation, and control of bus transport systems: A literature review. Transportation Research Part B: Methodological, 77, 38-75.

isango! Limited (2015). Hop-On Hop-Off. Retrieved April, 2015 from http://www.hop-on-hop-off-bus.com/about-us

Lumsdon, L. M. (2006). Factors affecting the design of tourism bus services. Annals of Tourism Research, 33(3), 748-766.

Public-Private Infrastructure Advisory Facility (2006). Factors Influencing Bus System Effienciency - Route Planning. Retrieved September 15, 2015 from http://www.ppiaf.org/sites/ppiaf.org/files/documents/toolkits/

Sorussa, J. (2014). Optimizing the synchronization of multiple bus routes at multiple transfer points assuming stochastic bus journey times (Master's Thesis). University of Wisconsin-Milwaukee, Wisconsin, USA. 